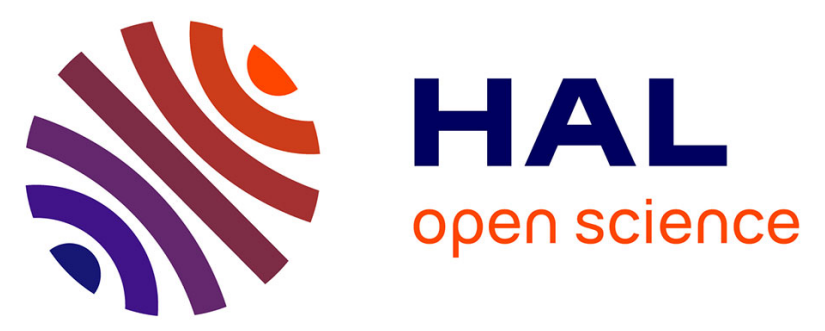

\title{
Diazoxide-induced insulin deficiency greatly reduced muscle protein synthesis in rats: involvement of eIF4E
}

Sandrine Sinaud, Michèle Balage, Gérard Bayle, Dominique Dardevet, Thomas C. Vary, Scot R. Kimball, Leonard S. Jefferson, Jean Grizard

\section{- To cite this version:}

Sandrine Sinaud, Michèle Balage, Gérard Bayle, Dominique Dardevet, Thomas C. Vary, et al.. Diazoxide-induced insulin deficiency greatly reduced muscle protein synthesis in rats: involvement of eIF4E. AJP - Endocrinology and Metabolism, 1999, 276 (1), pp.E50-E61. hal-02689352

\section{HAL Id: hal-02689352 \\ https://hal.inrae.fr/hal-02689352}

Submitted on 1 Jun 2020

HAL is a multi-disciplinary open access archive for the deposit and dissemination of scientific research documents, whether they are published or not. The documents may come from teaching and research institutions in France or abroad, or from public or private research centers.
L'archive ouverte pluridisciplinaire HAL, est destinée au dépôt et à la diffusion de documents scientifiques de niveau recherche, publiés ou non, émanant des établissements d'enseignement et de recherche français ou étrangers, des laboratoires publics ou privés. 
You might find this additional information useful...

This article cites 41 articles, 23 of which you can access free at:

http://ajpendo.physiology.org/cgi/content/full/276/1/E50\#BIBL

This article has been cited by 8 other HighWire hosted articles, the first 5 are:

Effect of insulin on human skeletal muscle protein synthesis is modulated by insulin-induced changes in muscle blood flow and amino acid availability

S. Fujita, B. B. Rasmussen, J. G. Cadenas, J. J. Grady and E. Volpi

Am J Physiol Endocrinol Metab, October 1, 2006; 291 (4): E745-E754.

[Abstract] [Full Text] [PDF]

Leucine-Supplemented Meal Feeding for Ten Days Beneficially Affects Postprandial Muscle Protein Synthesis in Old Rats

I. Rieu, C. Sornet, G. Bayle, J. Prugnaud, C. Pouyet, M. Balage, I. Papet, J. Grizard and D.

Dardevet

J. Nutr., April 1, 2003; 133 (4): 1198-1205.

[Abstract] [Full Text] [PDF]

Exercise Effects on Muscle Insulin Signaling and Action: Invited Review: Role of insulin in translational control of protein synthesis in skeletal muscle by amino acids or exercise

S. R. Kimball, P. A. Farrell and L. S. Jefferson

J Appl Physiol, September 1, 2002; 93 (3): 1168-1180.

[Abstract] [Full Text] [PDF]

Pulse Protein Feeding Pattern Restores Stimulation of Muscle Protein Synthesis during the Feeding Period in Old Rats

M.-A. Arnal, L. Mosoni, D. Dardevet, M.-C. Ribeyre, G. Bayle, J. Prugnaud and P. Patureau

Mirand

J. Nutr., May 1, 2002; 132 (5): 1002-1008.

[Abstract] [Full Text] [PDF]

Postprandial Stimulation of Muscle Protein Synthesis in Old Rats Can Be Restored by a Leucine-Supplemented Meal

D. Dardevet, C. Sornet, G. Bayle, J. Prugnaud, C. Pouyet and J. Grizard

J. Nutr., January 1, 2002; 132 (1): 95-100.

[Abstract] [Full Text] [PDF]

Medline items on this article's topics can be found at http://highwire.stanford.edu/lists/artbytopic.dtl on the following topics:

Chemistry .. Phosphorylation State

Oncology .. Protein Synthesis

Biochemistry .. Muscle Proteins

Biochemistry .. Initiation Factors

Medicine .. Insulin

Physiology .. Rats

Updated information and services including high-resolution figures, can be found at: http://ajpendo.physiology.org/cgi/content/full/276/1/E50

Additional material and information about AJP - Endocrinology and Metabolism can be found at: http://www.the-aps.org/publications/ajpendo

This information is current as of September 3, 2010.

AJP - Endocrinology and Metabolism publishes results of original studies about endocrine and metabolic systems on any level of organization. It is published 12 times a year (monthly) by the American Physiological Society, 9650 Rockville Pike, Bethesda MD 20814-3991. Copyright @) 1999 by the American Physiological Society. ISSN: 0193-1849, ESSN: 1522-1555. Visit our website at http://www.the-aps.org/. 


\title{
Diazoxide-induced insulin deficiency greatly reduced muscle protein synthesis in rats: involvement of el $\mathrm{F} 4 \mathrm{E}$
}

\author{
SANDRINE SINAUD, ${ }^{1}$ MICHELE BALAGE, ${ }^{1}$ GERARD BAYLE, ${ }^{1}$ DOMINIQUE DARDEVET, ${ }^{1}$ \\ THOMAS C. VARY, ${ }^{2}$ SCOT R. KIMBALL, ${ }^{2}$ LEONARD S. J EFFERSON ${ }^{2}$ AND J EAN GRIZARD ${ }^{1}$ \\ IInstitut National de la Recherche Agronomique et Centre de Recherche en Nutrition \\ Humaine d'Auvergne, Unité d'Etude du Métabolisme Azoté, 63122 Ceyrat, France; \\ and ${ }^{2}$ Department of Cellular and Molecular Physiology, The Pennsylvania State \\ University College of Medicine, Hershey, Pennsylvania 17033
}

\begin{abstract}
Sinaud, Sandrine, Michèle Balage, Gérard Bayle, Dominique Dardevet, Thomas C. Vary, Scot R. Kimball, Leonard S. J efferson, and J ean Grizard. Diazoxideinduced insulin deficiency greatly reduced muscle protein synthesis in rats: involvement of el F 4E. Am. J . Physiol. 276 (Endocrinol. Metab. 39): E50-E61, 1999.-We have investigated the effect of a postprandial acute insulin deficiency induced by diazoxide injection on rat skeletal muscle protein synthesis. Diazoxide administration lowered plasma insulin $>85 \%$ within $3 \mathrm{~h}$ after injection, whereas other hormones (insulin-like growth factor I, glucagon, corticosterone) involved in the regulation of muscle protein synthesis were not altered significantly compared with control animals. The fractional rate of muscle protein synthesis, measured in vivo, was reduced significantly $(\mathrm{P}<0.05)$ in epitrochlearis $(-46 \%)$, gastrocnemius $(-41 \%)$, and soleus $(-35 \%)$. The reduction in protein synthesis did not result from a reduced total RNA content but was associated with diminished translation efficiency. Analysis of ribosomal subunits revealed that the decreased translation efficiency resulted from an impairment in the initiation phase of protein synthesis. Diazoxideinduced insulin deficiency was associated with a dramatic decrease in eukaryotic initiation factor (elF) 4G bound to elF 4E and a 2.5-fold increase in the amount of the el F 4E - 4Ebinding protein 1 (BP1) complex. In contrast, diazoxide injection did not change either the relative amount of el $\mathrm{F} 4 \mathrm{E}$ present in gastrocnemius or its phosphorylation state. These results indicate that an acute insulin deficiency significantly decreases postprandial muscle protein synthesis by modulating the interaction between $4 \mathrm{E}-\mathrm{BP} 1$, elF4G, and el F4E to control translation initiation.
\end{abstract}

postprandial insulin deficiency; eukaryotic initiation factors 4E and 4G; 4E-binding protein 1; translation initiation

INSULIN PLAYS a major role in the regulation of muscle protein anabolism. In vitro studies have firmly established that insulin per se stimulates protein synthesis and inhibits protein degradation in skeletal muscle $(9$, $13,19,25)$. However, in vivo studies have been less conclusive, especially concerning the ability of insulin to stimulate protein synthesis. Most in vivo studies have failed to demonstrate a stimulatory effect of the hormone on muscle protein synthesis in either humans or animals (review in Ref. 38). In fact, only a few studies have shown an increase in skeletal muscle protein

The costs of publication of this article were defrayed in part by the payment of page charges. The article must therefore be hereby marked "advertisement" in accordance with 18 U.S.C. Section 1734 solely to indicate this fact. synthesis after insulin administration in normal, healthy volunteers $(5,6)$ or young postabsorptive rats $(1,15)$. Consequently, the involvement of insulin in the regulation of muscle protein synthesis in vivo has been mainly investigated in insulin-deficient states.

Decreasing the plasma insulin concentration by either experimental diabetes or starvation usually causes a significant reduction in the rate of protein synthesis in rat skeletal muscles $(1,2,11,22,27,33)$, which results from an impairment in the initiation phase of protein synthesis $(18,37)$. Insulin replacement restores protein synthesis to control values. These observations have been interpreted to indicate a unique role for insulin in controlling protein synthesis. However, insulin deficiency is often associated with disturbances in plasma substrates (amino acids) and other hormones [insulin-like growth factor I (IGF-I), glucocorticoids, glucagon, etc.; review in Ref. 32], which could modify protein synthesis. Hypoinsulinemia causes a drastic decrease in plasma IGF-I concentrations and IGF-I mRNA content in most tissues of diabetic or fasted rats $(7,16,42)$. Because rates of protein synthesis in gastrocnemius are linearly correlated with the muscle IGF-I content (26), decreases in protein synthesis observed in insulin-deficient states may be due to a decreased I GF-I content.

In the present study, we investigated the effect of an acute insulin deficiency in fed rats using a specific inhibitor of insulin secretion (the diazoxide). Skeletal muscle protein synthesis is greatly stimulated in response to food intake. However, the role of postprandial insulin secretion in this regulation is not clearly defined yet. Only few studies using anti-insulin antibodies $(30,36,42)$ demonstrated that insulin was involved in the stimulation of muscle protein synthesis after oral feeding. Diazoxide injection, by depressing postprandial insulinemia, allows direct examination of effects of insulin on skel etal muscle protein synthesis in vivo and themechanisms through which insul in modulates translation initiation. Other hormones involved in the regulation of protein synthesis (I GF-I, corticosterone, glucagon) were not altered significantly compared with control animals.

\section{MATERIALS AND METHODS}

\section{Animals}

Male Wistar rats weighing $70 \mathrm{~g}$ were purchased from IFFA CREDO (L'Arbresle, France) and were housed individually under controlled environmental conditions (temperature $22^{\circ} \mathrm{C}$; 
12-h dark period starting at 0900). They were allowed food (composition given in $\mathrm{g} / \mathrm{kg}$ dry matter in Ref. 3) and water ad libitum. Rats were acclimated to their surroundings for 5 days before the experimental protocol.

\section{Experimental Procedure}

The experimental design is shown in Fig. 1. Two types of experiments (I and II) were performed on the 6th day when the animals reached a mean body weight of $103.1 \pm 1.4 \mathrm{~g}$. In all experiments, $1 \mathrm{~h}$ after the beginning of the dark period, rats were fed for $1 \mathrm{~h}$. They consumed $2.96 \pm 0.17$ and $3.04 \pm$ $0.28 \mathrm{~g}$ (means $\pm \mathrm{SE}$ ) of dry matter in experiments of typel and II, respectively, on the day of the experiment. Food was then withdrawn, and the animals were randomly divided into the following two groups: the control group (C) and the diazoxideinjected group (DZ). The DZ group immediately received an intraperitoneal injection of diazoxide $(20 \mathrm{mg}$ in $3 \mathrm{ml}$ of $0.05 \mathrm{~N}$ sodium hydroxide/100 g body wt; Sigma Chemical), whereas the $\mathrm{C}$ group received only the vehicle (Fig. 1).

Experiments of type I were designed to investigate the effect of diazoxide administration on 1) plasma hormones (insulin, IGF-I , glucagon, and corticosterone), plasma metabolites [glucose, $\beta$-hydroxybutyrate, nonesterified fatty acids (NEFA), and free amino acids], and in vitro protein metabolism at 1, 2, and $3 \mathrm{~h}$ after diazoxide injection or 2) ribosomal subunit distribution and initiation factor regulation $2 \mathrm{~h}$ after diazoxide injection. In these studies, animals were anesthe tized with pentobarbital sodium (18 mg/100 g body wt) just before sample collection. For examination of in vitro protein metabolism, epitrochlearis muscles were dissected intact for incubations, immediately transferred to plastic tubes, preincubated for $30 \mathrm{~min}$ at $37^{\circ} \mathrm{C}$ in K rebs-Henseleit buffer supple mented with $5 \mathrm{mM}$ glucose, $5 \mathrm{mM}$ HEPES, $0.17 \mathrm{mM}$ leucine,
$0.20 \mathrm{mM}$ valine, $0.10 \mathrm{mM}$ isoleucine, and 0.1\% BSA (99\% fatty acid free), and saturated with a $95 \% \mathrm{O}_{2}-5 \% \mathrm{CO}_{2}$ gas mixture as previously described $(9,10,14)$. The muscles were then transferred to fresh medium of the same composition containing $0.5 \mathrm{mM}\left[{ }^{14} \mathrm{C}\right.$ ]phenylalanine $(0.15 \mu \mathrm{Ci} / \mathrm{ml})$ and incubated again for $60 \mathrm{~min}$ at $37^{\circ} \mathrm{C}$. To assess any direct effects of diazoxide on muscle protein metabolism, protein synthesis and breakdown were determined in vitro by incubating $C$ muscles (epitrochlearis) in the absence or presence of an excess of diazoxide $(0.4 \mathrm{mg} / \mathrm{ml})$ according to the protocol as described in Measurement of in vitro protein metabolism. To measure plasma hormone and metabolite concentrations, blood samples were withdrawn by heart puncture in noninjected animals (time 0 , basal values) and 1, 2, and $3 \mathrm{~h}$ after injection of vehicle or diazoxide and were rapidly centrifuged. The plasma was decanted and frozen until analyzed for hormones and metabolites. F or ribosomal subunits and initiation factor analysis, gastrocnemius muscles were removed quickly, rinsed in ice-cold saline, weighed, and homogenized in the corresponding buffer. The homogenates were treated as described in Ribosomal Subunit and Initiation Factor Analysis.

Experiments of typell were performed to analyze the effect of diazoxide and exogenous insulin replacement on rates of skeletal muscle protein synthesis in vivo. The experimental design included the following four groups: 1) C; 2) DZ; 3) DZ group that received a low dose (see below) of insulin (Ins 1); and 4) DZ group that received a high dose of insulin (Ins 2). Muscle protein synthesis was measured in vivo by the incorporation of radioactive phenylalanine using the flooding dose method according to Garlick and Grant (15). This procedure reduces uncertainties about the labeling of the tracer amino acids in the precursor pool for protein synthesis.

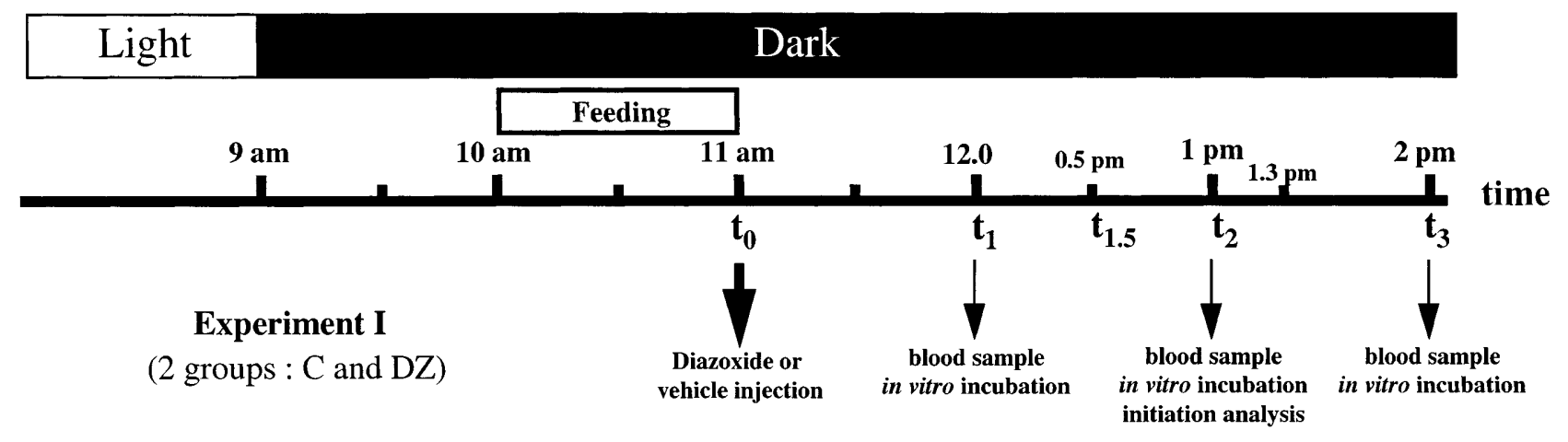

\section{Experiment II}

(4 groups : C, DZ, Ins1 and Ins2)

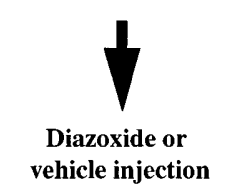

Diazoxide or
vehicle injection

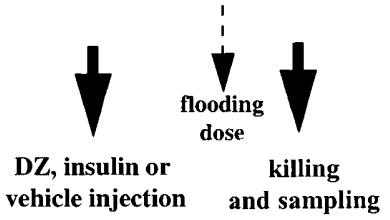

Fig. 1. Experimental protocols. All animals received food $1 \mathrm{~h}$ after the beginning of the dark period and had free access to food for $1 \mathrm{~h}$. At the end of feeding, animals were divided into the following 2 groups: the control (C) and the diazoxide-injected (DZ) group injected with vehicle or diazoxide according to the protocol described in MATERIALS AND METHODS. In type I experiments, an additional group that did not receive any injection was included to give basal values. Plasma metabolites and hormones were measured at time 0 in nontreated rats (food is also removed at this time) and 1, 2, and $3 \mathrm{~h}$ after injections in vehicle or DZ rats. In vitro muscle protein turnover was only measured 1, 2, and $3 \mathrm{~h}$ after vehicle or diazoxide injections. I nitiation factor analysis was only performed at $2 \mathrm{~h}$ after injections. In type II experiments, a second diazoxide injection was performed $1.5 \mathrm{~h}$ after the initial injection in DZ group, whereas $C$ group received the vehicle. In addition, two additional groups were included [DZ group that received low dose of insulin (Ins 1) and DZ group that received high dose of insulin (Ins 2)], which were injected with insulin at the 1.5-h time point. In vivo protein synthesis was then measured using a flooding dose of phenylalanine, which was injected 20 min before killing. $t_{0}, t_{1}, t_{1.5}, t_{2}$, and $t_{3}$, Time at $0,1,1.5,2$, and $3 h$, respectively. 
A preliminary experiment showed that the flooding dose of phenylalanine significantly increased plasma insulin in the DZ group (from $6.2 \pm 1.5$ to $34.75 \pm 10.3 \mu \mathrm{U} / \mathrm{ml}$ before and 20 min after the bolus, respectively), whereas it did not in the $C$ group. High doses of phenylalanine are known to transiently elevate plasma insulin, especially when given by rapid injection (29). Because diazoxide blocks insulin secretion without inhibiting its biosynthesis, insulin may have accumulated in $\beta$-cells and could have been liberated after the bol us injection of phenylalanine. Such a phenomenon could explain the rise in plasma insulin observed in DZ rats in contrast to the $C$ group. To prevent the spike in plasma insulin due to the phenylalaninebolus, the DZ group received a second intraperitoneal injection of diazoxide ( $15 \mathrm{mg}$ in $2 \mathrm{ml}$ of $0.05 \mathrm{~N}$ sodium hydroxide/100 g body wt) $1.5 \mathrm{~h}$ after the first injection. Under these conditions, plasma insulin concentrations were not elevated by injection of the phenylalanine $(6.5 \pm 1.8$ and $7.1 \pm$ $2.5 \mu \mathrm{U} / \mathrm{ml}$ before and after the bolus injection, respectively). At that time, Ins 1 and Ins 2 groups received a subcutaneous injection of insulin (Lente MC Insulin; Novo Pharmaceuticals) diluted in saline ( $197 \pm 9$ and $280 \pm 6 \mathrm{mU}$ in $0.5 \mathrm{ml} / 100 \mathrm{~g}$ body wt in Ins 1 and Ins 2 groups, respectively). These doses of insulin were chosen to partly or completely replace the plasma insulin concentrations (Table 1). The $\mathrm{C}$ group received the vehicle. The bolus injection of $L-\left[U-{ }^{14} \mathrm{C}\right]$ phenylalanine (30 $\mu \mathrm{Ci}, 300 \mathrm{mM} ; 2 \mathrm{ml} / 100 \mathrm{~g}$ body wt) was given subcutaneously 2 $\mathrm{h}$ after the first diazoxide injection. Twenty minutes after the injection of radioactivity (i.e., $0.8 \mathrm{~h}$ after insulin or diazoxide injections and $2.3 \mathrm{~h}$ after the first diazoxide injection), the rats were anesthetized with pentobarbital sodium as described in preceding paragraphs. Soleus (in all groups) and gastrocnemius and epitrochlearis (only in C and DZ groups) were quickly excised, rinsed in cold saline, and blotted. They were then rapidly weighed and frozen in liquid nitrogen.

\section{Analytical Methods}

Free amino acid extraction. Plasma amino acids (experiment I) and tissue free amino acids (experiment II) were measured using the method described elsewhere (1). Briefly, plasma or frozen muscle samples were homogenized in $8 \mathrm{vol}$ of ice-cold $10 \%$ trichloroacetic acid (TCA). The acid-soluble fraction containing free amino acids was separated from the protein precipitate by centrifugation $(10,000 \mathrm{~g}$ for $20 \mathrm{~min})$, and TCA was removed by chromatography on a column of cation exchange resin (AG50 X8, 100-200 mesh; Bio-Rad, Richmond, CA). For plasma amino acid determination, the $\mathrm{NH}_{4} \mathrm{OH}$ effluent was dried and resuspended in $0.2 \mathrm{M}$ lithium buffer (pH 2.2). Total plasma free amino acid concentrations were then determined by liquid chromatography (Resin BT 2410; Biotronik) with an automatic amino acid analyzer (LC

Table 1. Plasma insul in and glucoseconcentrations in experiment II

\begin{tabular}{lcl}
\hline \hline Group & Plasma Insulin, $\mu \mathrm{U} / \mathrm{ml}$ & Plasma Glucose, $\mathrm{mg} / 100 \mathrm{ml}$ \\
\hline C & $66.2 \pm 19.0$ & $161 \pm 0.1$ \\
DZ & $7.1 \pm 2.5^{* \dagger}$ & $638 \pm 0.6^{*} \dagger \neq$ \\
Ins 1 & $22.4 \pm 3.8^{*}$ & $297 \pm 0.6$ \\
Ins 2 & $41.6 \pm 4.5$ & $172 \pm 0.1$ \\
\hline
\end{tabular}

Values are means $\pm \mathrm{SE}$. At time 0 , animals were injected with either vehicle (C group) or diazoxide. Diazoxide-treated rats were divided into 3 groups $1.5 \mathrm{~h}$ later: the $\mathrm{DZ}$ group that received a second injection of diazoxide and Ins 1 and I ns 2 groups injected with low and high doses of exogenous insulin, respectively, as described in MATERIALS AND METHODS (experiment II). Plasma insulin and glucose were determined 50 min later at the time of death. There were 4 rats in $C$ group, 7 rats in DZ group, and 5 rats in Ins 1 and Ins 2 groups. $* P<$ 0.05 vs. $C . \dagger P<0.05$ vs. Ins 2 . $\ddagger P<0.05$ vs. Ins 1 .
3000; Biotronik) using norleucine as an internal standard. For tissue free amino acids, the $\mathrm{NH}_{4} \mathrm{OH}$ effluent was dried and resuspended in water $(\mathrm{pH}$ 7.0) for derivatization and HPLC analysis (see Amino acid derivatization procedure and determination of phenylalanine specific radi oactivity).

Protein-bound aminoacid extraction. Tissue protein precipitates were washed two more times in 10\% TCA and finally one time in $0.2 \mathrm{M}$ perchloric acid (PCA). Pellets were resuspended in $0.3 \mathrm{M} \mathrm{NaOH}$, and an aliquot was used for protein measurement (see Measurement of in vitro protein metabolism). Pellets were precipitated again in $2 \mathrm{M}$ PCA overnight at $4^{\circ} \mathrm{C}$ and centrifuged (10,000 $\mathrm{g}$ for $15 \mathrm{~min})$. The corresponding supernatant was filtered, and RNA content was determined in this supernatant using the method described by Manchester and Harris (28). The protein pellets were then hydrolyzed in $6 \mathrm{~N} \mathrm{HCl}$ for $24 \mathrm{~h}$ at $110^{\circ} \mathrm{C}$, dried, and resuspended in water (pH 7.0) for amino acid derivatization.

Amino acid derivatization procedure and determination of phenylalanine specific radioactivity. Twenty microliters of tissue free amino acid extract and $500 \mu$ of protein-bound amino acid extract underwent the o-phthaladehyde (OPA) derivatization at room temperature for 3 min using $40 \mu \mathrm{l}$ (for free amino acids) and $500 \mu \mathrm{l}$ (for protein-bound amino acids) of an OPA reagent. The OPA reagent was a mix of $50 \mathrm{mg}$ OPA (Sigma Chemical) dissolved in $1 \mathrm{ml}$ methanol with $9 \mathrm{ml}$ borate buffer [ $800 \mathrm{mM}, \mathrm{pH} 10.4$, Normapur RP (Prolabo)] and $100 \mu \mathrm{l} \beta$-mercaptoethanol. Appropriate amino acid mixtures were used as standards over the range of $0.2-2.0 \mu \mathrm{mol}$ phenylalanine/ml. The derivatized amino acid extracts or standards were then injected in a Kontron HPLC system. Separation using a gradient of solvent $A$ (phosphoric buffer containing $0.1 \mathrm{M} \mathrm{Na}_{2} \mathrm{HPO}_{4}-\mathrm{H}_{2} \mathrm{O}$ and $0.1 \mathrm{M} \mathrm{H}_{3} \mathrm{PO}_{4}$ adjusted to $\mathrm{pH} 7.0$ using $\mathrm{NaOH}$ ) and sol vent $\mathrm{B}$ (solvent A supplemented with methanol, acetonitrile, and ultrapure water at 30, 35, 15 , and $20 \%$, respectively, vol/vol) was achieved at room temperature on a reverse-phase Interchim Spherisorb ODS2 column $(5 \mu \mathrm{m}, 250 \times 4.6 \mathrm{~mm}$ and $250 \times 10 \mathrm{~mm}$ for free and for protein-bound amino acids, respectively). The corresponding flow rates were 1.00 and $4.25 \mathrm{ml} / \mathrm{min}$, respectively. Chromatograms were processed by the integrator, and phenylalanine concentrations were calculated from peak areas of phenylalanine standards. The phenylalanine-associated radioactivity was determined by collecting the fractions corresponding to the phenylalanine peak. Radioactivity was measured by liquid scintillation spectrometry. The specific radioactivity (dpm/nmol) was calculated by dividing the phenylalanineassociated radioactivity $(\mathrm{dpm} / \mathrm{ml})$ by phenylalanine concentration $(\mathrm{nmol} / \mathrm{ml})$.

Measurement of in vitro protein metabolism. At the end of the incubation, muscles were blotted, weighed, and homogenized in 10\% TCA. TCA insoluble material was washed three times with $10 \%$ TCA and solubilized for $1 \mathrm{~h}$ in $1 \mathrm{M} \mathrm{NaOH}$ at $37^{\circ} \mathrm{C}$ for determination of radioactivity incorporated into protein. Protein contents of tissues (experiments I and II) were determined in the $\mathrm{NaOH}$ solubilized material from TCA pellets (see Protein-bound amino acid extraction) by a colorimetric reaction using the bicinchoninic acid method (Pierce, Rockford, IL) with crystalline bovine serum albumin as a standard. Protein degradation was estimated as described elsewhere $(9,10,44)$. Because tyrosine is neither synthesized nor degraded in muscle, release of the amino acid from muscle in the incubation medium reflects net protein breakdown. Tyrosine in the incubation medium was assessed fluorometrically (46).

Plasma substrates. Plasma glucose was determined enzymatically using glucose oxidase (Boerhinger). Plasma NEFA and $\beta$-hydroxybutyrate were determined enzymatically using an autoanalyzer $(4,8)$. 
Plasma hormones. Plasma insulin was determined by direct radioimmunoassay (RIA) with a commercial kit (ERIA Diagnostics Pasteur, Sanofi, F rance) using human insulin as standard. In the RIA, the insulin used as injection material (porcine-bovine mixture) to Ins 1 and Ins 2 groups crossreacted with the antibody in a similar manner to human insulin standard, whereas rat insulin was more reactive. Plasma glucagon was determined by RIA with the Pharmacia kit (Serono). Total plasma I GF-I underwent a $0.5 \mathrm{M}$ hydrochloric acid extraction process and a $\mathrm{C}_{18}$ Sep Pak (octadodecyl silica cartridge) purification before RIA, which was performed using a commercial kit (Sorin Biomedica). Plasma corticosterone was also determined by RI A (35).

\section{Calculations}

In vivo protein synthesis was expressed as fractional synthesis rates (FSR in \%/day), which were calculated according to the method described (15): FSR $=100 \times S_{b} /\left(S_{a} \times t\right)$, where $S_{b}$ is the specific radioactivity of protein-bound phenylalanine, $\mathrm{S}_{\mathrm{a}}$ the specific radioactivity of tissue free phenylalanine, and the incorporation time ( $20 \mathrm{~min}$ ), expressed in days. An estimate of translational efficiency was obtained by calculating the amount of protein synthesized per milligram RNA and per day (mg protein $\cdot$ day $^{-1} \cdot \mathrm{mg} \mathrm{RNA}^{-1}$ ). Injection of phenylalanine resulted in elevated plasma free phenylalanine levels after $20 \mathrm{~min}(772 \pm 30 \mathrm{nmol} / \mathrm{ml}$ instead of $54 \pm 4$ $\mathrm{nmol} / \mathrm{ml}$ after and before phenylalanine injection, respectively). In preliminary experiments using $C$ and DZ rats, we verified that free phenylalanine specific radioactivity reached similar values in both plasma and muscle 10 min after injection of the same flooding dose and remained constant thereafter (data not shown). Due to this slow rate of equilibration, the calculated FSR likely underestimated the actual rates of protein synthesis in both groups. In the present experiments, the flooding dose was al so effective in equalizing the free phenylalanine specific radioactivity in plasma and tissues; free phenylalanine specific radioactivity expressed in percent of the injected phenylalanine was $92.2 \pm 5.0$ and $84.1 \pm 4.4 \%$ in plasma and muscle, respectively. No significant effect of diazoxide or insulin injections on the phenylalanine specific radioactivity was noted.

In vitro protein synthesis in epitrochlearis muscle was expressed as nanomoles of phenylalanine incorporated per milligram of protein per hour. Proteolysis was determined as previously described $(9,10,44)$. It was then estimated as the sum of the net tyrosine release in the incubation medium and protein synthesis (phenylalanine incorporation in muscle proteins was expressed in terms of tyrosine equivalents; see Ref. 44). Proteolysis was expressed as nanomoles of tyrosine per milligram of protein per hour.

\section{Ribosomal Subunit Analysis}

For isolation of ribosomal subunits, fresh muscle $(0.5 \mathrm{~g}$ of gastrocnemius) was homogenized in $6 \mathrm{vol}$ of ice-cold homogenization buffer [in mM: 20 Tris, pH 7.4, $250 \mathrm{KCl}, 5 \mathrm{MgCl}_{2}, 1$ dithiothreitol (DTT), and 2 vanadyl ribonucleoside] using a Polytron homogenizer. Simultaneously, $0.5 \mathrm{~g}$ of gastrocnemius of the second hindlimb of the rat was homogenized in the same buffer except vanadyl ribonucleoside was omitted for assay of total RNA. The homogenates were centrifuged at $10,000 \mathrm{~g}$ for $20 \mathrm{~min}$ at $4^{\circ} \mathrm{C}$. Aliquots of the supernatants (0.8-1 ml), to which Triton X-100/deoxycholate had been added to final concentrations of $0.1 \%$, were layered on $15-$ $50 \%$ sucrose density gradients that were formed using homogenization buffer. Gradients were centrifuged for $18 \mathrm{~h}$ at 27,000 revolutions $/ \mathrm{min}$ at $4^{\circ} \mathrm{C}$ in a Beckman SW28 rotor using a Beckman L8.70M ultracentrifuge. After centrifuga- tion, the gradients were fractionated ( $\sim 1 \mathrm{ml} /$ fraction) with a peristaltic pump and a fraction collector (Gilson Medical Electronics, Middleton, WI ). The absorbance at 260 min was monitored with a Secoman spectrophotometer (Secoman, Domont, France). RNA contents of the homogenates and sucrose density gradient fractions were measured spectrophotometrically as the absorbance at $260 \mathrm{~nm}\left(\mathrm{~A}_{32,6} \mu \mathrm{g} / \mathrm{ml}=1\right.$ at $260 \mathrm{~nm}$ ), corrected for absorbance at $232 \mathrm{~nm}$, after alkaline hydrolysis (12). The quantities of RNA in the $60 \mathrm{~S}$ and $40 \mathrm{~S}$ ribosomal subunit fractions were expressed relative to the total amount of RNA layered on the gradient ( $\mu \mathrm{g}$ RNA/mg homogenate RNA).

\section{Initiation Factor Analysis}

For initiation factor analysis, $0.25 \mathrm{~g}$ of fresh muscle (gastrocnemius) were homogenized in 7 vol of buffer $A[20 \mathrm{mM}$ HEPES, pH 7.4, 100 mM KCl, 0.2 mM EDTA, 2 mM EGTA, 1 $\mathrm{mM}$ DTT, $50 \mathrm{mM} \mathrm{NaF}, 50 \mathrm{mM} \beta$-glycerophosphate, $0.1 \mathrm{mM}$ phenylmethylsulfonyl fluoride (PMSF), $1 \mathrm{mM}$ benzamidine, $0.5 \mathrm{mM}$ sodium vanadate, and $1 \mu \mathrm{M}$ microcystin $L R$ ] by use of a Polytron homogenizer. The homogenate was centrifuged at $10,000 \mathrm{~g}$ for $10 \mathrm{~min}$ at $4^{\circ} \mathrm{C}$, and the supernatant was stored at $-80^{\circ} \mathrm{C}$ until analysis.

Determination of the phosphorylation state of eukaryotic initiation factor 4E. The phosphorylated and unphosphorylated forms of eukaryotic initiation factor (el F) 4E in gastrocnemius were separated by isoelectric focusing on a slab gel and quantitated by protein immunoblot analysis, as described previously $(24,41)$, using a monoclonal antibody against el $F 4 \mathrm{E}$. The bl ots were visualized using chemiluminescence as described by the manufacturer's instructions (Amersham). Films were scanned, and images were analyzed as described previously (41).

Quantification of 4E-BP1-EF4E and elF4G-elF4E complexes. The association of el F 4E with $4 E-B P 1$ and el F 4G was examined as described previously $(24,25)$. el $F 4 E$ and $4 E$ binding protein 1 (BP1)-el F 4E and el F 4G - el F 4E complexes were immunoprecipitated from aliquots of $10,000-\mathrm{g}$ supernatants using an anti-el F 4E monoclonal antibody. The antibodyantigen complex was collected by incubation for $1 \mathrm{~h}$ with goat anti-mouse Biomag IgG beads (PerSeptive Diagnostics). Before use, the beads were washed in $1 \%$ nonfat dry milk in buffer $\mathrm{B}(50 \mathrm{mM}$ Tris hydrochloride, $\mathrm{pH} 7.4,150 \mathrm{mM} \mathrm{NaCl}, 5$ mM EDTA, 0.1\% $\beta$-mercaptoethanol, 0.5\% Triton X-100, 50 $\mathrm{mM} \mathrm{NaF}, 50 \mathrm{mM}$-glycerophosphate, $0.1 \mathrm{mM}$ PMSF, $1 \mathrm{mM}$ benzamidine, and $0.5 \mathrm{mM}$ sodium vanadate). The beads were captured by use of a magnetic stand and were washed two times with buffer $B$ and one time with buffer $B$ containing 500 $\mathrm{mM}$, rather than $150 \mathrm{mM}, \mathrm{NaCl}$. Protein bound to the beads was eluted by resuspending the beads in sodium dodecyl sulfate-sample buffer and boiling the sample for $5 \mathrm{~min}$. The beads were collected by centrifugation, and the supernatants were subjected to electrophoresis either on a $7.5 \%$ polyacrylamide gel for quantification of elF $4 \mathrm{G}$ or on a $15 \%$ polyacrylamide gel for quantification of $4 \mathrm{E}-\mathrm{BP} 1$ and el $\mathrm{F} 4 \mathrm{E}$. Proteins were then electrophoretically transferred to a polyvinylidene difluoride membrane. The membranes were incubated with either a mouse anti-human el F4E antibody, a rabbit anti-rat 4E-BP1 antibody, or a rabbit anti-el F 4G antibody for $1 \mathrm{~h}$ at room temperature. The blots were then developed using an enhanced chemiluminescence Western blotting kit (Amersham). Films were scanned and quantitated as described previously (41).

\section{Statistics}

Data are expressed as means $\pm \mathrm{SE}$. The significance of differences between groups in each experiment was analyzed 
by ANOVA to test for overall differences among groups followed by a Student's t-test to test differences among the means only when the ANOVA indicated a significant difference among group means. Differences among means were considered significant at $\mathrm{P}<0.05$.

\section{RESULTS}

Plasma Hormones and Metabolites After I njection of Diazoxide

The time course (experiment I) for the effect of diazoxide on plasma insulin concentrations is shown in Fig. 2. Before diazoxide or vehicle injections, the postprandial mean plasma insulin concentration was $49.0 \pm$ $10.3 \mu \mathrm{U} / \mathrm{ml}$ in all animals (see time 0 on Fig. 2). Diazoxide administration induced a significant decrease in postprandial plasma insulin concentration at each time after injection (3- to 4-fold decrease vs. C group, $\mathrm{P}<0.05$, Fig. 2). In the $\mathrm{C}$ group, the plasma insulin concentration remained unchanged over the $3 \mathrm{~h}$. Pilot experiments showed that the decrease in plasma insulin in the DZ group was reversible. Insulin concentrations returned to values observed in control fed rats $5 \mathrm{~h}$ after the diazoxide injection (30.5 \pm 3.0 and $36.7 \pm 10.3 \mu \mathrm{U} / \mathrm{ml}$ in DZ and C groups, respectively). In experiment II, plasma insulin was also very low in DZ rats compared with $C$ (Table 1 ). Insulin injection of the DZ rats resulted in a dose-dependent increase in plasma insulin in the Ins 1 and Ins 2 groups (Table 1). As expected, the higher dose of insulin (Ins 2 group) restored plasma insulin concentration closer to that of the $C$ group, whereas the low dose did not.

Other plasma hormones (I GF-I, glucagon, and corticosterone) were measured just at the end of feeding in nontreated animals (basal values) and 1, 2, and $3 \mathrm{~h}$

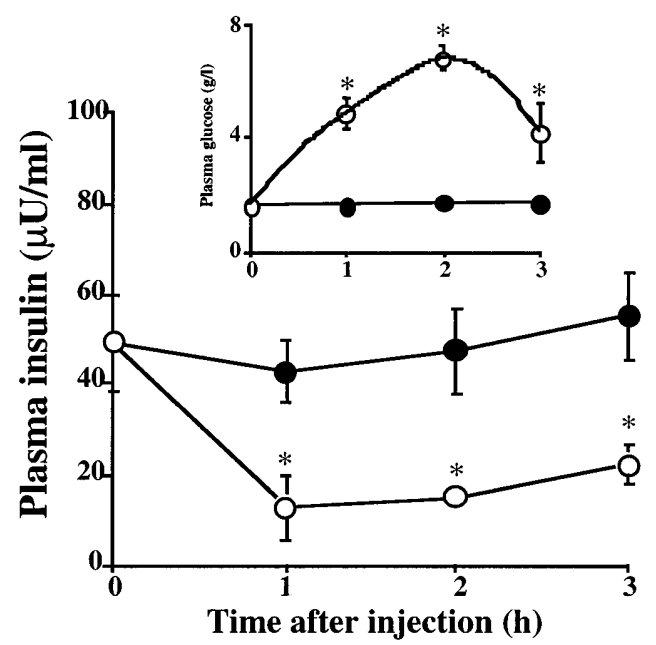

Fig. 2. Time course of plasma insulin and glucose in diazoxideinjected $(O)$ and control $(\bullet)$ rats in experiment I. Rats were injected intraperitoneally with diazoxide (DZ group) or vehicle (C group) at time 0 , as described in MATERIALS AND METHODS, whereas some animals did not receive any injection to give basal values (time 0 ). Plasma insulin was measured by radioimmunoassay at $0,1,2$, and $3 \mathrm{~h}$ after injection. Plasma glucose was determined by an enzymatic method using the same samples and is shown in inset. Values are means \pm SE of 5 animals in each group at each time. $* \mathrm{P}<0.05$ between $C$ and $D Z$ groups at the same time. after vehicle or diazoxide injections in experiment I. Unlike insulin, plasma hormone levels were not significantly different between $C$ and DZ groups at any of the times examined after injections (Table 2). However, plasma IGF-I and corticosterone were both significantly increased 1 and $3 \mathrm{~h}$ after injections of either vehicle or diazoxide compared with basal values. Plasma glucagon did not change except $2 \mathrm{~h}$ after vehicle injection in the $\mathrm{C}$ group. Plasma glucose was constant in the $C$ group in experiment I for the 0 - to 3 -h period $(1.68 \pm 0.08 \mathrm{~g} / \mathrm{l})$. Diazoxide injection induced hyperglycemia at 1,2 , and $3 \mathrm{~h}$ ( $\mathrm{P}<0.05$ vs. $C$ group) with a maximum value at $2 \mathrm{~h}(6.79 \pm 0.40 \mathrm{~g} / \mathrm{l}, \mathrm{P}<0.05 \mathrm{vs}$. values at 1 and 3 h, Fig. 2). Similar glucose concentrations were also observed in the DZ groups during experiment II at tissue harvest, suggesting that neither the phenylalanine injection nor the second diazoxide injection had an effect on plasma glucose. Injection of insulin in DZ animals partly corrected the diazoxideinduced hyperglycemic state (Table 1). Plasma glucose remained el evated with the lower insulin dose, whereas it reached a value observed in the $C$ group with the higher dose.

Plasma $\beta$-hydroxybutyrate remained constant in the $C$ group during the 0 - to 3 -h period. It was greatly increased in the DZ group at all times $(P<0.05$, Fig. 3A). Plasma NEFA showed an increase in the $C$ group during the 0 - to $2-\mathrm{h}$ period and then decreased at $3 \mathrm{~h}$. The same temporal pattern was observed in the DZ group, but the peak occurred earlier (at $1 \mathrm{~h}$ ), and the values at 2 and $3 \mathrm{~h}$ remained elevated. As a result, only values at 1 and $3 \mathrm{~h}$ were significantly higher in the DZ group than in the $C$ group ( $P<0.05$, Fig. 3B ).

Plasma amino acids were also assessed at 1,2 , and $3 \mathrm{~h}$ after diazoxide injection (Table 3). Most essential amino acids were similar in the DZ and $C$ groups at $1 \mathrm{~h}$. The decrease $(P<0.05)$ in plasma arginine in the $D Z$ group was an exception. Two hours after diazoxide injection, there was a significant increase in plasma leucine along with a decrease in plasma methionine and tyrosine in the DZ compared with the $C$ group. The change in plasma leucine was maintained at $3 \mathrm{~h}$ with additional increases in other branched-chain amino acids (valine and isoleucine) and a decrease in plasma arginine in the DZ compared with $C$ group (Table 3 ). The effect of diazoxide injection to modulate amino acid concentrations was more pronounced on nonessential than on essential plasma amino acids, whatever the time after diazoxide injection (Table 3).

\section{Muscle Protein Synthesis}

The effect of diazoxide injection on muscle protein synthesis was measured in vivo $2 \mathrm{~h}$ after injection of diazoxide. Diazoxide-induced hypoinsulinemia reduced protein synthesis in each muscle examined $(-35.2 \%$, $P<0.005$ vs. $C$ in soleus; $-41.2 \%, P<0.005$ vs. $C$ in gastrocnemius; $-46.5 \%, P<0.0001$ vs. $C$ in epitrochlearis; Fig. 4A). Diazoxide per se had no direct effect on muscle protein metabolism because incubation of $C$ muscles in medium with a high diazoxide concentration did not induce any change in either muscle protein 
Table 2. Plasma IGF-I, glucagon, and corti costerone concentrations in DZ group and C group in experiment I

\begin{tabular}{|c|c|c|c|c|c|c|c|}
\hline & $\begin{array}{l}\text { Basal Values } \\
\text { (time0) }\end{array}$ & \multicolumn{3}{|c|}{ C Group } & \multicolumn{3}{|c|}{ DZ Group } \\
\hline $\begin{array}{l}\text { IGF-I, nmol/l } \\
\text { Glucagon, pg/ml } \\
\text { Corticosterone, ng/ml }\end{array}$ & $\begin{array}{c}5.98 \pm 0.95 \\
369 \pm 29 \\
41 \pm 15\end{array}$ & $\begin{array}{l}11.3 \pm 1.4^{*} \\
430 \pm 63 \\
105 \pm 10^{*}\end{array}$ & $\begin{array}{c}9.7 \pm 1.8 \\
527 \pm 46^{*} \\
84 \pm 14\end{array}$ & $\begin{array}{l}9.9 \pm 1.1^{*} \\
349 \pm 19 \\
116 \pm 27^{*}\end{array}$ & $\begin{array}{l}13.2 \pm 1.9 * \\
308 \pm 17 \\
152 \pm 6^{*}\end{array}$ & $\begin{array}{c}7.7 \pm 1.0 \\
488 \pm 50 \\
87 \pm 11\end{array}$ & $\begin{array}{l}11.6 \pm 0.4^{*} \\
431 \pm 73 \\
125 \pm 29^{*}\end{array}$ \\
\hline
\end{tabular}

Values represent means \pm SE of 5 rats at each time in each group. IGF-I, insulin-like growth factor I. At the end of food intake, animals were divided into 3 groups: DZ group, C group, and a group that did not receive any injection (this group yiel ded basal values). In treated groups, plasma hormones were measured 1,2 , and $3 \mathrm{~h}$ after injections. *Significantly different from basal values at P $<0.05$ (ANOVA); no statistically significant difference between DZ and C groups was observed at the same time.

synthesis $(0.40 \pm 0.06$ vs. $0.37 \pm 0.04 \mathrm{nmol}$ phenylalanine $\cdot \mathrm{mg}_{\text {protein }}{ }^{-1} \cdot \mathrm{h}^{-1}$ in the absence or presence of diazoxide, respectively) or breakdown (1.30 \pm 0.06 vs. $1.33 \pm 0.13 \mathrm{nmol}$ tyrosine $\cdot \mathrm{mg}$ protei $\mathrm{n}^{-1} \cdot \mathrm{h}^{-1}$, in the absence or presence of diazoxide, respectively) measured in vitro. These data indicate that impaired protein synthesis observed in skeletal muscles from DZ-treated rats in vivo resulted from DZ-induced postprandial insulin deficiency. To further examine the specific role of insulin on protein synthesis in DZinduced hypoinsulinemia, insulin was injected $1.5 \mathrm{~h}$ after diazoxide injection (Ins 1 and Ins 2 groups). I njection of insulin restored plasma insulin concentrations (Table 1). Because all three muscles studied in the DZ group exhibited the same reduction in protein synthesis after diazoxide injection, fractional protein synthesis rates were only determined in soleus muscle from rats subjected to insul in replacement. As shown in Fig. 4A, inset, insulin injections to DZ-treated rats normalized FSR to values observed in $C$ rats (i.e., values from Ins 1 and Ins 2 groups did not differ significantly from the $C$ group). Although FSR was not statistically significantly different between Ins 1 and Ins 2 groups, the increase of protein synthesis after insulin injection was more pronounced with the larger insulin dose.

Rates of protein synthesis are dependent on both the muscle ribosome content and the translational efficiency of ribosomes. Therefore, the content of RNA in the muscles was determined. No significant differences in the RNA content were observed between any of the muscles (Fig. 4B) or treatments studied (Fig. 4B, inset), indicating that a decrease in the abundance of ribosomes for protein synthesis was not responsible for the changes in muscle protein synthesis. In contrast to RNA content, translational efficiency was significantly reduced after treatment with $\mathrm{DZ}$ (Fig. $4 \mathrm{C}$ ). The magnitude of the decrease in translational efficiency paralleled the reduction in protein synthesis. Furthermore, administration of insulin to DZ-treated rats resulted in a stimulation of translation efficiency. Consequently, the changes observed in in vivo FSR were entirely explained by changes in the ribosomal efficiency (Fig. $4 C$, inset).

To examine potential mechanisms through which DZ-induced hypoinsulinemia reduced the translational efficiency, the content of free $40 \mathrm{~S}$ and 605 ribosomal subunits was measured in gastrocnemius from $C$ and DZ groups $2 \mathrm{~h}$ after injections. As shown in Fig. 5, diazoxide injection increased the RNA contents of the 605 and 405 subunit fractions, displaying an accumulation of $40 S$ and 605 ribosomal subunits in DZ animals compared with $\mathrm{C}$ animals.

To further investigate the mechanism through which acute postprandial insulin deficiency modulated translation initiation, the amount and extent of phosphorylation of el F 4E was examined in gastrocnemius from $C$ and $\mathrm{DZ}$ rats $2 \mathrm{~h}$ after the injection of diazoxide. As shown in Table 4, neither the content nor phosphorylation state of el $\mathrm{F} 4 \mathrm{E}$ was significantly altered by diazoxide treatment of the animals. Another mechanism through which protein synthesis might be regulated is the association of el F4E with el F4G or $4 E-B P 1$. Western blot analysis of el F4E immunoprecipitates with
A

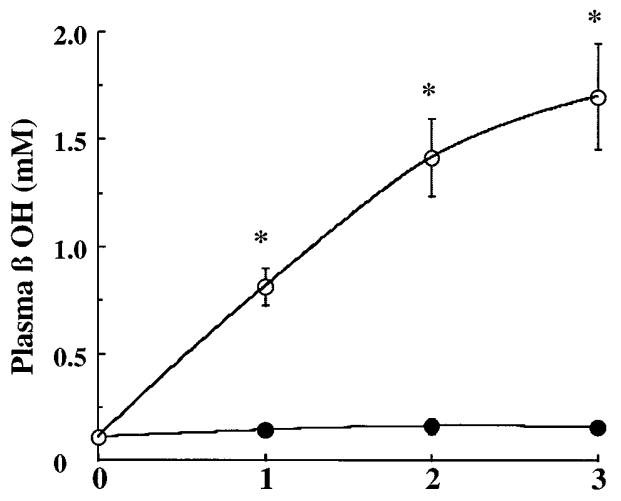

B

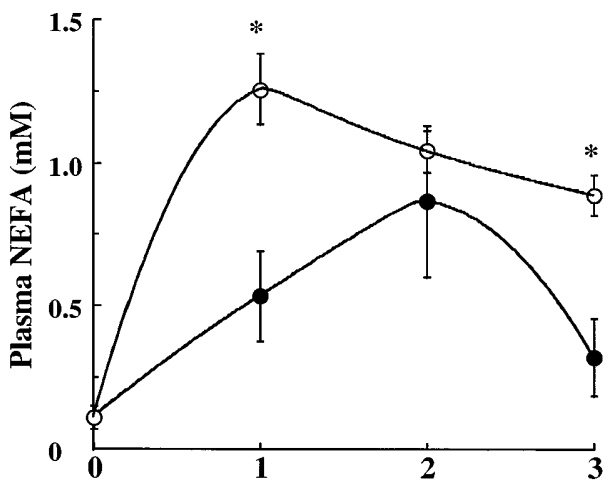

Fig. 3. Time course of plasma $\beta$-hydroxybutyrate $(\beta-\mathrm{OH} ; A)$ and nonesterified fatty acids (NEFA; $B$ ) in diazoxide injected $(O)$ and control $(\bullet)$ rats in experiment I. Rats were injected with diazoxide (DZ group) or vehicle (C group) at time 0, as described in MATERIALS AND METHODS, whereas some animals did not receive any injection to give basal values (time 0 ). Values are means \pm SE of 5 animals in each group at each time. $* P<0.05$ between $C$ and DZ groups at the same time.

Time after injection (h) 
Table 3. Individual plasma amino acid concentrations ( $\mu \mathrm{mol} / \mathrm{l})$ in control and diazoxidegroups 1,2 , and $3 \mathrm{~h}$ after injections in experiment $\mathrm{I}$

\begin{tabular}{|c|c|c|c|c|c|c|}
\hline & \multicolumn{3}{|c|}{ C Group } & \multicolumn{3}{|c|}{ DZ Group } \\
\hline Threonine & $307.8 \pm 35.6$ & $349.6 \pm 34.5$ & $261.0 \pm 25.7$ & $251.4 \pm 47.3$ & $267.7 \pm 14.3$ & $271.4 \pm 27.2$ \\
\hline Isoleucine & $78.6 \pm 6.9$ & $74.7 \pm 3.4$ & $66.3 \pm 5.4$ & $69.1 \pm 3.8$ & $91.8 \pm 9.2$ & $122.2 \pm 8.5^{*}$ \\
\hline Leucine & $109.7 \pm 24.5$ & $81.9 \pm 8.9$ & $110.1 \pm 13.0$ & $90.0 \pm 11.3$ & $139.9 \pm 18.0 *$ & $183.5 \pm 13.8 *$ \\
\hline Phenylalanine & $60.3 \pm 6.9$ & $53.6 \pm 3.0$ & $72.1 \pm 2.7$ & $54.7 \pm 2.8$ & $61.8 \pm 3.3$ & $60.6 \pm 3.1$ \\
\hline Lysine & $634.3 \pm 34.4$ & $530.1 \pm 87.9$ & $628.7 \pm 38.1$ & $500.6 \pm 28.0$ & $567.7 \pm 17.8$ & $558.3 \pm 25.8$ \\
\hline Histidine & $72.4 \pm 5.9$ & $76.6 \pm 15.1$ & $106.1 \pm 15.6$ & $59.0 \pm 6.0$ & $86.8 \pm 9.2$ & $101.1 \pm 5.2$ \\
\hline Tyrosine & $50.1 \pm 7.5$ & $47.1 \pm 2.0$ & $52.4 \pm 4.2$ & $39.0 \pm 4.3$ & $32.9 \pm 2.8^{*}$ & $45.3 \pm 4.6$ \\
\hline Serine & $345.5 \pm 20.2$ & $366.2 \pm 29.4$ & $385.3 \pm 38.2$ & $325.8 \pm 19.7$ & $396.5 \pm 25.0$ & $345.0 \pm 23.2$ \\
\hline Alanine & $766.5 \pm 55.0$ & $844.2 \pm 52.5$ & $703.1 \pm 57.2$ & $534.1 \pm 59.9 *$ & $442.0 \pm 77.8^{*}$ & $374.6 \pm 54.2^{*}$ \\
\hline Aspartic acid & $19.9 \pm 2.2$ & $20.9 \pm 0.7$ & $18.8 \pm 1.7$ & $14.5 \pm 2.5^{*}$ & $10.5 \pm 1.6^{*}$ & $12.4 \pm 1.5^{*}$ \\
\hline Asparagine & $92.6 \pm 11.4$ & $97.8 \pm 3.0$ & $97.7 \pm 7.9$ & $67.7 \pm 7.1^{*}$ & $79.0 \pm 3.9$ & $86.7 \pm 8.4$ \\
\hline Glutamic acid & $211.7 \pm 19.1$ & $203.8 \pm 21.2$ & $212.4 \pm 29.3$ & $123.0 \pm 6.6^{*}$ & $107.8 \pm 18.2 *$ & $102.2 \pm 4.3^{*}$ \\
\hline Ornithine & $52.5 \pm 6.9$ & $53.1 \pm 7.7$ & $67.2 \pm 3.1$ & $38.3 \pm 4.2$ & $52.5 \pm 9.0$ & $53.9 \pm 2.4$ \\
\hline
\end{tabular}

Data are means \pm SE in $\mu$ mol/l. In treated groups, plasma hormones were measured 1,2 , and $3 \mathrm{~h}$ after injections. *P $<0.05$ (ANOVA) between $C$ and DZ groups at the same time. ND, not determined.

either el F 4G or 4E-BP1 antibodies revealed that el F 4G associated with el $\mathrm{F} 4 \mathrm{E}$ was not detectable in gastrocnemius from DZ rats compared with $C$ (Table 4). In contrast, diazoxide injection caused a 2.5-fold increase in the amount of $4 \mathrm{E}-\mathrm{BP} 1$, which coprecipitated with el F 4E (Table 4). Taken together, these findings demonstrate that an acute postprandial insulin deficiency dramatically depressed the association of el F4G, with elF4E favoring formation of the $4 E-B P 1 \cdot e l F 4 E$ complex.

Using incubated muscles from DZ and C rats, we assessed the effect of in vivo diazoxide-induced insulin deficiency on protein breakdown measured in vitro. As expected, protein degradation was increased $(P<0.05)$ in muscles from DZ-treated rats compared with $C$ animals (Fig. 6A). Protein synthesis determined in vitro was significantly decreased in incubated epitrochlearis from rats injected with diazoxide compared with $\mathrm{C}$ although the difference between the two groups was less pronounced than in vivo (Fig. 6B).

\section{DISCUSSION}

Insulin deficiency in vivo induced by diabetes or starvation $(1,2,11,22,27,33)$ is commonly associated with a reduction in the rate of skeletal muscle protein synthesis. Insulin replacement therapy or refeeding generally restores skeletal muscle protein synthesis to $\mathrm{C}$ values. These observations suggest that insulin modulates protein synthesis. However, it is not clear from such studies whether the effect of insulin deficiency on protein synthesis is directly related to changes in insulin per se or to metabolic disturbances as a consequence of the hypoinsulinemia. Insulin deficiency is associated with changes in circulating hormones (e.g., I GF-I , glucocorticoi ds, gl ucagon) and plasma amino acids (see Ref. 32 for a review), which could also regulate protein synthesis. In the present study, using diazoxide as a specific inhibitor of insulin secretion, we show that suppression of plasma insulin by diazoxide did not significantly change any of the other hormones investigated (glucagon, IGF-I, corticosterone) compared with vehicle-treated animals. However, diazoxide treatment induced a dramatic reduction in skel etal muscle protein synthesis in growing rats. Exogenous insulin replacement abolished this defect. These results demonstrate that insulin is intimately involved in the regulation of skeletal muscle protein synthesis after feeding.

I GF -I is a potent stimulator of muscle protein synthesis (9). Tissue IGF-I mRNA and plasma IGF-I are usually gradually decreased after hypoinsulinemia (7, $15,32,42$ ). In the present experiment, plasma IGF-I exhibited the same time course in DZ and C groups. Presumably due to feeding, postprandial values were higher than basal values ( $P<0.05$ only at 1 and $3 \mathrm{~h}$ ). In spite of low values in the DZ group at $2 \mathrm{~h}$, postprandial plasma IGF-I was not significantly different between the two groups at any time considered. It is unlikely that such a change in plasma IGF-I could affect protein synthesis. Indeed, in vitro protein synthesis did not show any change in either group whatever the time after injections. Thus the lack of difference in plasma IGF -I concentrations between $C$ and DZ rats precludes the involvement of this growth factor in the decrease in protein synthesis. It is well known that plasma I GF-I is associated with binding proteins, which could provide important modulation of the effects of IGF-I without changing total plasma values. Unfortunately, we have no information on these binding proteins in the present experiment.

Insulin deprivation also generally results in el evated plasma glucocorticoids, which are known to decrease 
A

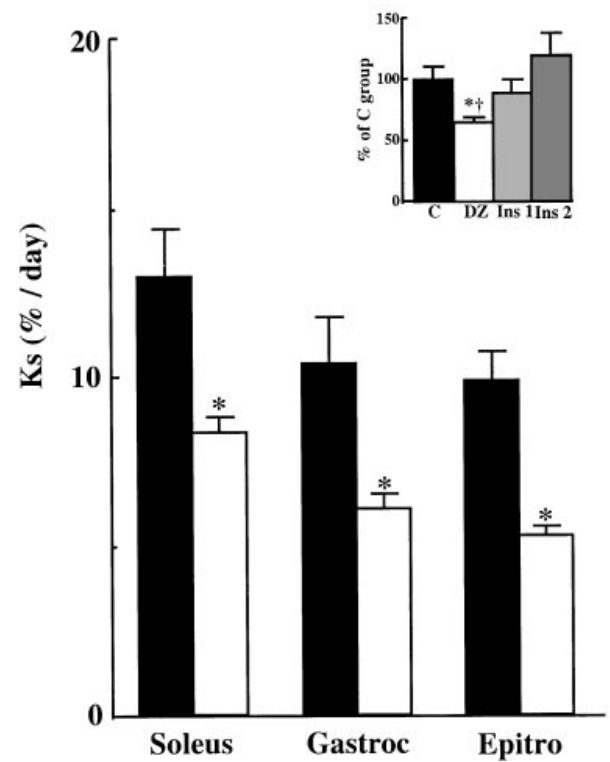

B

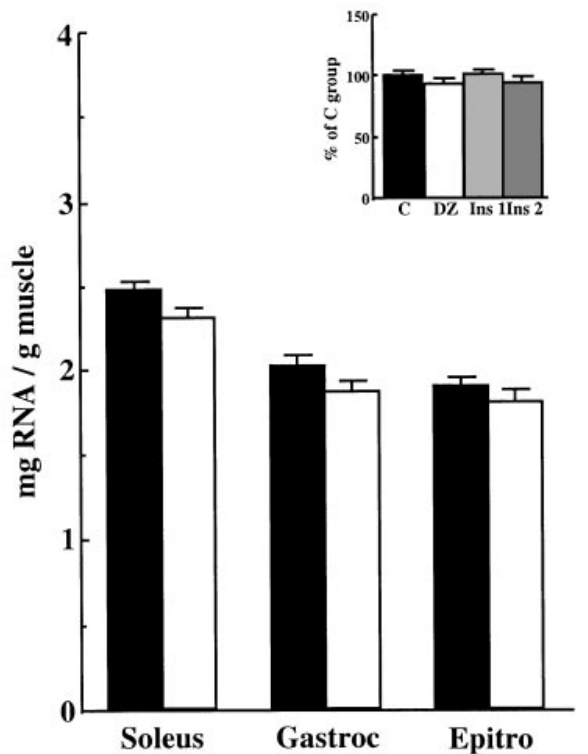

C

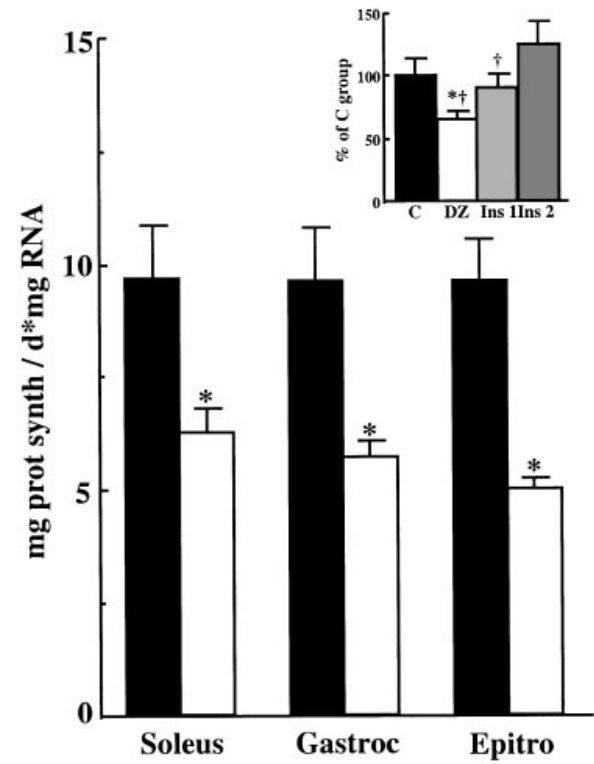

Fig. 4. Rates of protein synthesis (A), RNA content (B), and protein synthesis efficiency (C) in skeletal muscles from diazoxide-injected (open bars) and control (filled bars) rats. Animals received 2 injections of either diazoxide (DZ group) or vehicle (C group) according to the experimental design presented in Fig. 1 for typell experiments. In vivo protein synthesis was determined in soleus, gastrocnemius (Gastroc), and epitrochlearis (E pitro) muscles using the phenylalanine flooding dose method. Protein synthesis is expressed as fractional synthetic rate $\left(\mathrm{K}_{\mathrm{s}}\right.$ in $\% /$ day $)$, and protein synthesis efficiency is expressed as $\mathrm{mg}$ protein synthesized $\cdot \mathrm{mg} \mathrm{RNA}^{-1}$. day ${ }^{-1}$. Protein content in soleus, gastrocnemius, and epitrochlearis were, respectively, $184.2 \pm 4.8$ vs. $171.8 \pm 4.4,188.6 \pm 7.8$ vs. $175.1 \pm 5.9$, and $186.4 \pm 3.2$ vs. $172.5 \pm 5.4 \mathrm{mg} / \mathrm{g}$ muscle in C and DZ groups, respectively (means \pm SE for 4 and 7 rats in each group). I nsets represent the effect of exogenous insulin replacement on rates of protein synthesis, RNA content, and protein synthesis efficiency in soleus of some diazoxide-injected rats. According to the experimental design presented on Fig. 1 for typell experiments and described in MATERIALS AND METHODS, some diazoxide-injected rats received an injection of exogenous insulin instead of the second diazoxide injection at low (Ins 1 group) or high dose (Ins 2 group). Values are presented as a percentage of values in control group. Protein content in soleus from Ins 1 and Ins 2 groups were, respectively, $187.9 \pm 3.8$ and $180.3 \pm 5.2 \mathrm{mg} / \mathrm{g}$ muscle (means \pm SE of 5 rats in each group). Values are means \pm SE of 4 (C group), 7 (DZ group), and 5 (Ins 1 and Ins 2 groups) animals. $* P<0.05$ compared with $C$ group; $† P<0.05$ compared with I ns 2 group.

protein synthesis $(30,45)$. Plasma corticosterone was not significantly different between DZ and C animals, suggesting that glucocorticoids most likely are not the cause of alterations in the protein synthesis observed in DZ rats. Both vehicle and diazoxide injections induced

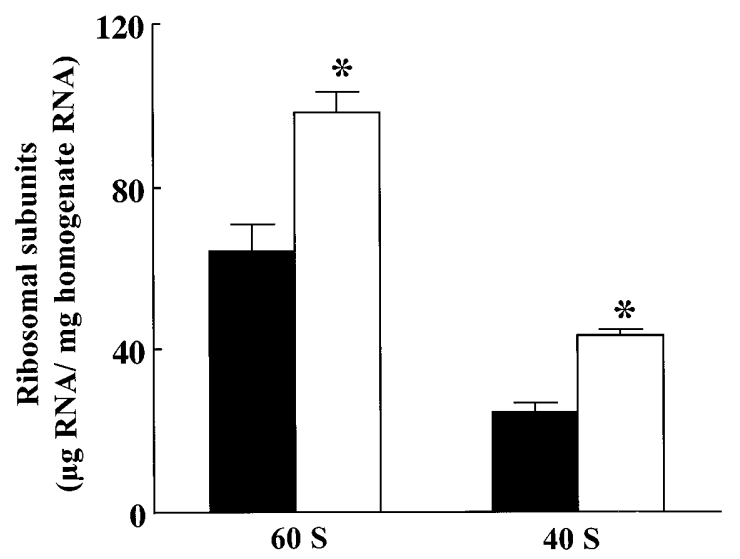

Fig. 5. Effect of diazoxide injection on levels of free ribosomal subunits in gastrocnemius. Muscle samples were taken from control or diazoxide-treated rats $2 \mathrm{~h}$ after injection. $60 \mathrm{~S}$ and $40 \mathrm{~S}$ ribosomal subunits were isolated on sucrose density gradients as described in MATERIALS AND METHODS. Values are means \pm SE of 6 animals in each group. $* P<0.05$ between $C$ and $D Z$ groups. an increase in plasma corticosterone (not statistically significant $2 \mathrm{~h}$ after injection). However, corticosterone levels were still in the range of physiological values compared with stress values $(20,39)$. Moreover, plasma corticosteronerequired to inhibit muscleprotein synthesis is generally much more el evated than in the present experiment $(40,45)$. There was no change in plasma

Table 4. Effect of diazoxideinjection on phosphorylation of $\mathrm{AF} 4 \mathrm{E}$, content of el $F 4 E$, and el F 4E associated with either $4 \mathrm{E}-\mathrm{BP} 1$ or $\mathrm{e} \mathrm{F} 4 \mathrm{G}$ in experiment I

\begin{tabular}{lll}
\hline \hline & \multicolumn{1}{c}{ C Group } & \multicolumn{1}{c}{ DZ Group } \\
\hline el F4E phosphorylation, \% of total & $55.40 \pm 2.49$ & $47.97 \pm 5.33$ \\
el F4E content, arbitrary units & $2,129 \pm 95$ & $1,685 \pm 181$ \\
el F4E associated with 4E-BP 1, arbi- & & \\
$\quad$ trary units & $32.83 \pm 1.47$ & $80.03 \pm 6.94 *$ \\
el F4E associated with el F4G, arbi- & & \\
$\quad$ trary units & $221.14 \pm 73.4$ & ND
\end{tabular}

Values are means \pm SE of 4- 6 animals in each group. Initiation factors in rat gastrocnemius were analyzed $2 \mathrm{~h}$ after injection of either diazoxide (DZ group) or vehicle (C group). Phosphorylation of eukaryotic iniation factor (elF)4E was expressed as a percentage of total el F 4E in skeletal muscle. *P $<0.001$, DZ vs. C group. ND, not detectable. 


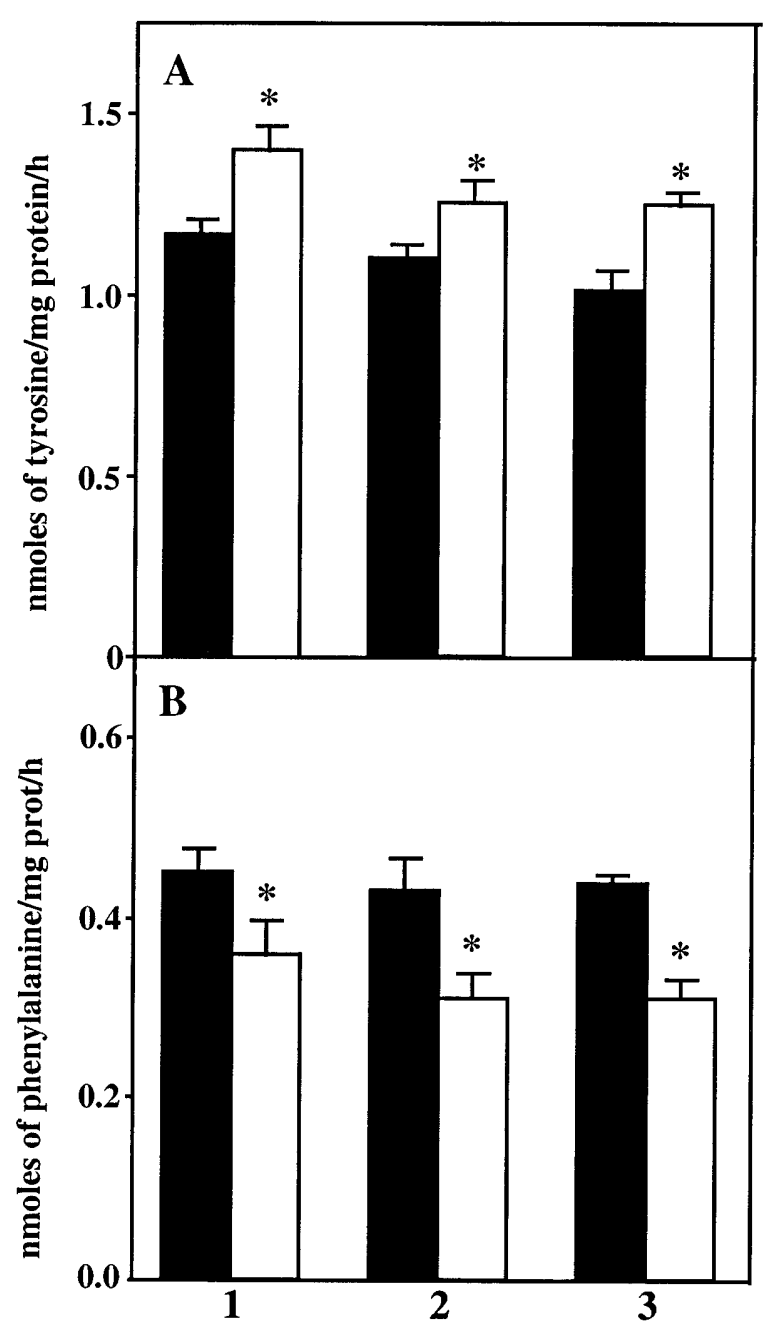

Time after injection (h)

Fig. 6. Effect of diazoxide injection on in vitro protein degradation (A) and synthesis (B). Animals were injected with either diazoxide (DZ group, open bars) or vehicle (C group, filled bars) and at 1, 2, and $3 \mathrm{~h}$ later; epitrochlearis muscles were isolated and incubated as described in MATERIALS AND METHODS. Proteolysis is expressed as nmol of tyrosine released $\cdot \mathrm{mg}$ protein ${ }^{-1} \cdot \mathrm{h}^{-1}$, and protein synthesis is expressed as $\mathrm{nmol}$ phenylalanine incorporated. $\mathrm{mg}$ protein $\mathrm{n}^{-1} \cdot \mathrm{h}^{-1}$. Values represent means \pm SE of 5 animals in each group at each time. $* \mathrm{P}<0.05$ between $\mathrm{C}$ and $\mathrm{DZ}$ groups at each time.

glucagon between $\mathrm{C}$ and $\mathrm{DZ}$ rats, which excluded any contribution of this hormone in the impairment of muscle protein synthesis.

Besides hormones, plasma metabolites, especially amino acids, can regulate muscle protein synthesis (review in Ref. 43). Insulin deprivation induced by starvation or insulin infusion without concomitant administration of exogenous amino acids results in a decrease in plasma amino acids $(38,43)$. Under such conditions, a decrease in the availability of amino acids is associated with a reduction in protein synthesis. Conversely, reduced protein synthesis caused by insulin deficiency in experimental diabetes is associated with a marked increase in amino acids (especially branched-chain amino acids; see Ref. 47). In the present experiment, moderate changes in essential plasma amino acids were observed $2 \mathrm{~h}$ after diazoxide injection (time at which protein synthesis was determined). The most significant increase in plasma branched-chain amino acids occurred at $3 \mathrm{~h}$ after diazoxide injection. However, if such an increase affected protein synthesis, it would tend to underestimate the differences observed between C and DZ groups because amino acids would tend to increase rather than decrease protein synthesis $(15,43)$. Thus it is also unlikely that changes in the concentration of plasma amino acids were responsible for the alterations in protein metabolism after diazoxide treatment.

As expected, diazoxide-induced hypoinsulinemia resulted in a large increase in plasma glucose. However, glucose per se does not have any effect on muscle protein synthesis either in vivo (15) or in the perfused rat hemicorpus (19). DZ rats also showed an increase in plasma NEFA and $\beta$-hydroxybutyrate. Although infusion of these metabolites has been shown to modify whole body leucine fluxes (oxidation is decreased with NEFA; oxidation and protein synthesis are increased with $\beta$-hydroxybutyrate; see Ref. 32), their direct effect on muscle protein synthesis has not been demonstrated clearly. Moreover, the increase in $\beta$-hydroxybutyrate that occurs in insulin-deficient rats would be expected to stimulate rather than inhibit muscle protein synthesis. Note that the vehicle per se was able to increase NEFA at $2 \mathrm{~h}$ in the $\mathrm{C}$ group. This increase might represent a catecholamine effect in response to $\mathrm{NaOH}$ injection in the peritoneum. However, no chemical peritonitis was visible at the time the animals were killed.

Even though vehicle or diazoxide injections induced some hormonal and metabolic perturbations, its seems likely that diazoxide-induced hypoinsulinemia is a suitablemodel to study therelationship between plasma insulin and skeletal muscle protein synthesis in vivo. Indeed, these alterations are in the physiological range and are not statistically significantly different between $\mathrm{DZ}$ and $\mathrm{C}$ rats. Moreover, the decrease in blood pressure resulting from diazoxide injection was not statistically significant compared with vehicle injection (45 \pm 5 vs. $58 \pm 2 \mathrm{mmHg}$ in $\mathrm{DZ}$ and $\mathrm{C}$ group under anesthesia, means \pm SE of 4 and 3 animals in each group obtained in a side experiment).

Because insulin deficiency can be induced in the postprandial state with diazoxide, the signal that elicits the stimulation of protein synthesis in response to feeding in skeletal muscle can be defined more clearly. Before the studies presented herein, the rise in plasma insulin caused by refeeding has been prevented either by using diabetic animals or by intravenous injection of anti-insul in antibodies. Such experiments have yielded conflicting results. In one experiment, anti-insulin antibodies completely suppressed the response of protein synthesis to feeding (36). In contrast, in two other studies $(30,42)$, the response was attenuated but was not prevented. Such studies imply that plasma insulin is an important component in the protein synthetic response to feeding. In contrast, a recent study using diabetic mice (42) showed that protein synthesis is 
stimulated by feeding in the absence of a rise in plasma insulin. This apparent discrepancy is probably a result of different plasma insulin concentrations in various studies. Thus anti-insulin antibodies cause an almost complete deprivation of insulin, whereas the plasma insulin in the diabetic animals used by Svanberg et al. (42) was only reduced to $50 \%$ of the value observed in control, fed animals. Overall, the results suggest that insulin is required, but is not sufficient alone, to stimulate protein synthesis.

In the present study, the potential mechanisms re sponsible for the inhibition of protein synthesis after injection of diazoxide were examined. As would be expected, total RNA content was not altered by the 2-h insulin deficiency caused by diazoxide. A decline in RNA content and therefore in ribosomes occurs only after longer durations of insulin deficiency. Consequently, the reduction in protein synthesis observed in DZ rats could be explained by an impairment of translational efficiency without any alteration in ribosome number. This observation is consistent with other reports using insulin-deficient states. For example, short-term fasting causes a reduction in translation initiation, whereas long-term fasts (beyond $24 \mathrm{~h}$ ) induce an additional decrease in ribosome numbers ( 1 , 27, 37). Similarly, experimental diabetes (2- to 7-day alloxan-treated rats) causes both an impairment in translational efficiency and a decrease in ribosomal capacity; insulin replacement for 50 min restores translation efficiency but not RNA content (11).

The decreased translational efficiency may result from an inhibition of peptide-chain initiation or el ongation/termination. Analysis of the distribution of ribosomal subunits between free particles and polysomes revealed an accumulation of free subunits in gastrocnemius from DZ rats compared with $C$ rats. Hence, diazoxide-induced hypoinsulinemia impaired the rate of protein synthesis in skeletal muscles through inhibition of initiation relative to elongation. Indeed, initiation of protein synthesis is a complex sequence of reactions that leads to the association of the $40 \mathrm{~S}$ and 605 ribosomal subunits (i.e., formation of the 805 initiation complex). If initiation becomes rate limiting for protein synthesis, free ribosomal subunits accumulate, and polysomes are depleted. Conversely, when initiation is accelerated, subunits are depleted and polysomes accumulate (review in Ref. 23). The 405 and 605 subunit accumulation in diazoxide-induced insulin deficiency agrees with other insulin-deficient states such as diabetes or starvation, where the inhibition of protein synthesis occurs by decreasing the rate of translation initiation $(18,21,27)$.

One of the most regulated steps in translation initiation is the binding of mRNA to the 40S subunit (34). This step involves several initiation factors constituting el $\mathrm{F} 4 \mathrm{~F}$, which catalyze the association. The component of el F 4F that binds to the $\mathrm{m}^{7} \mathrm{GTP}$ cap at the $5^{\prime}$ end of the mRNA is el $\mathrm{F} 4 \mathrm{E}$. The subsequent binding of the el F4E - mRNA complex to another initiation factor, el F4G, is a critical step in the formation of the $48 \mathrm{~S}$ preinitiation complex. Regulation of the binding of el F4E to el F4G involves another protein, 4E-BP1. In vitro, el F 4E can bind to either $4 \mathrm{E}-\mathrm{BP} 1$ or el F $4 \mathrm{G}$ but not at the same time (17). This finding in combination with the observation that the amino acid sequence of the el F4E binding domain of the two proteins is homologous suggests that el $\mathrm{F} 4 \mathrm{G}$ and $4 \mathrm{E}-\mathrm{BP} 1$ compete for binding to el $\mathrm{F} 4 \mathrm{E}$. The results of the present study demonstrate a reciprocal relationship between el $\mathrm{F} 4 \mathrm{E}$ binding to 4E-BP1 and el F4G. Moreover, the inhibition of protein synthesis observed in DZ rats results in an increase in 4E-BP1 bound to el F 4E concomitant with a dramatic decrease in binding of el F4E to el F4G. Similarly, long-term insulin deficiency, such as experimental diabetes (3-day alloxan treatment) or starvation, also results in an increase in the association of 4E-BP1 with elF4E, which is completely reversed by either insulin administration to diabetic rats or refeeding starved mice $(24,41)$. Taken together, these results suggest that insulin is involved directly in the association of el F4E with either $4 \mathrm{E}-\mathrm{BP} 1$ or el F $4 \mathrm{G}$ to regulate the initiation of protein synthesis.

Another mechanism through which the binding of mRNA to the 40S ribosomal subunit is regulated involves phosphorylation of el F4E. It has been shown that phosphorylation of elF4E in vitro increases its affinity for the $m^{7}$ GTP cap of mRNA (31), suggesting that phosphorylation of el F4E might enhance translation initiation. As observed in previous studies using experimental diabetic rats and insulin-treated rats (24), diazoxide-induced insulin deficiency did not alter the phosphorylation state of el F 4E compared with C rats, suggesting that, in vivo, insulin does not regulate translation initiation by modulating the phosphorylation of el F4E.

In conclusion, the present study has shown that skeletal muscle protein synthesis is greatly depressed in fed rats subjected to postprandial insulin deprivation caused by injection of a specific inhibitor of insulin secretion (i.e., diazoxide). The reduced skeletal muscle protein synthesis observed during postprandial diazoxide-induced insulin deficiency results from an inhibition of translation initiation. It is associated with increased formation of the 4E-BP 1-el F 4E complex and decreased formation of the el F 4G - el F 4E complex without alteration of the amount or phosphorylation state of el F 4E. The results allow us to conclude that short-term insulin deficiency $(2 \mathrm{~h})$ inhibits postprandial muscle protein synthesis by sequestering el $\mathrm{F} 4 \mathrm{E}$ into an inactive 4E-BP1-el F 4E complex. Such an animal model of hypoinsulinemia might be used to define the specific role of insulin in the regulation of skeletal muscle protein synthesis and to investigate insulin signaling.

We thank Hans-Peter Schmid for helpful advice regarding ribosomal subunit preparations. We also thank Caroline Buffière, Christian Lafarge, Marcel Sallas, Hélène Lafarge, and Sharon Rannels for technical assistance, J ean-Paul Chacornac for help in metabolite assays, and Michel Dalle for assessing corticosterone and blood pressure.

This work was supported in part by research grants from the Institut National de la Recherche Agronomique (France) and by National Institutes of Health Grants GM-39277 (T. C. Vary) and DK-15658 (L. S. J efferson). 
Address for reprint requests: $M$. Balage, Unité d'Etude du Métabolisme Azoté, INRA, Centre de Clermont-Theix, 63122 Saint GenésChampanelle, France.

Received 10 March 1998; accepted in final form 16 September 1998.

\section{REFERENCES}

1. Baillie, A. G. S., and P. J . Garlick. Responses of protein synthesis in different skeletal muscles to fasting and insulin in rats. Am. J . Physiol. 260 (Endocrinol. Metab. 23): E891-E896, 1991.

2. Baillie, A. G. S., and P. J . Garlick. Attenuated responses of muscle protein synthesis to fasting and insulin in adult female rats. Am. J . Physiol. 262 (Endocrinol. Metab. 25): E 1-E 5, 1992.

3. Balage, M., J . Grizard, D. Hui-Bon-Hoa, and G. Rosselin. Effect of dietary protein level on the first steps of glucagon action on rat liver plasma membranes. J . Nutr. 116: 1810-1819, 1986.

4. Barnouin, J ., N. EI Idibi, Y. Chilliard, J . P. Chacornac, and R. Lefaivre. Micro-dosage automatisé sans déprotéinisation du 3-hydroxybutyrate plasmatique chez les bovins (Abstract). Ann. Rech. Vét. 17: 129, 1986.

5. Bennet, W. M., A. A. Connacher, C. M. Scrimgeour, R. T. J ung, and M. J . Rennie. Euglycemic hyperinsulinemia augments amino acid uptake by human leg tissues during hyperaminoacidemia. Am. J . Physiol. 259 (Endocrinol. Metab. 22): E 185E 194, 1990.

6. Biolo, G., R. Y. D. Fleming, and R. R. Wolfe. Physiologic hyperinsulinemia stimulates protein synthesis and enhances transport of selected amino acids in human skeletal muscle. J . Clin. Invest. 95: 811- 819, 1995.

7. Bornfeldt, K. E., H. J . Arnquist, B. Enberg, L. S. Mathews, and G. Norstedt. Regulation of IGF-I and GH receptor gene expression by diabetes and nutritional state in rat tissues. J . Endocrinol. 122: 651-656, 1989.

8. Chilliard, Y., D. Bauchart, and J . Barnouin. Determination of plasma non esterified fatty acids in herbivores and man: a comparison of values obtained by manual or automatic chromatographic, titrimetric, colorimetric and enzymatic methods. Re prod. Nutr. Dev. 24: 469-482, 1984.

9. Dardevet, D., C. Sornet, D. Attaix, V. E. Baracos, and J . Grizard. Insulin-like growth factor-1 and insulin resistance in skeletal muscles of adult and old rats. Endocrinology 134: 1475-1484, 1994.

10. Dardevet, D., C. Sornet, D. Taillandier, I Savary, D. Attaix, and J . Grizard. Sensitivity and protein turnover response to glucocorticoids are different in skel etal musclefrom adult and old rats. Lack of regulation of the ubiquitin-proteasome proteolytic pathway in aging. J . Clin. Invest. 96: 2113-2119, 1995.

11. Flaim, K. E., M. B. Copenhaver, and L. S. J efferson. Effects of diabetes on protein synthesis in fast- and slow-twitch rat skeletal muscle. Am. J. Physiol. 239 (Endocrinol. Metab. 2): E88-E95, 1980.

12. Fleck, A., and H. N. Munro. The precision of ultraviolet absorption measurements in the schmidt-thannhauset procedure for nucleic acid estimation. Biochim. Biophys. Acta 55: 571-583, 1962

13. Fluckey, J . D., T. C. Vary, L. S. J efferson, W. J . Evans, and P. A. Farrell. Insulin stimulation of protein synthesis in rat skel etal muscle following resistance exercise is maintained with advancing age. J . Gerontol. B Psychol. Sci. Soc. Sci. 51: B323B330, 1996.

14. Fulks, R., J . B. Li, and A. L. Goldberg. Effects of insulin, glucose and aminoacids on protein turnover in rat diaphragm. J Biol. Chem. 250: 290-298, 1975.

15. Garlick, P. J ., and I. Grant. Amino acid infusion increases the sensitivity of muscle protein synthesis in vivo to insulin. Effect of branched-chain amino acids. Biochem. J . 254: 579- 584, 1988.

16. Goldstein, S., G. J . Sertich, K. R. Levan, and L. S. Phillips. Nutrition and somatomedin. XIX. Molecular regulation of insulinlike growth factor-1 in streptozotocin-diabetic rats. Mol. Endocrinol. 2: 1093-1100, 1988.

17. Haghighat, A., S. Mader, A. Pause, and N. Sonenberg. Repression of cap-dependent translation by $4 \mathrm{E}$-binding protein 1: competition with p220 for binding to eukaryotic initiation factor-4E. EMBO J . 14: 5701-5709, 1995.
18. Harmon, C. S., C. G. Proud, and V. M. Pain. Effects of starvation, diabetes and acute insulin treatment on the regulation of polypeptide-chain initiation in rat skeletal muscle. Biochem. J . 223: 687-696, 1984.

19. J efferson, L. S., J . B. Li, and S. R. Rannels. Regulation by insulin of amino acid release and protein turnover in the perfused rat hemicorpus. J . Biol. Chem. 252: 1476- 1483, 1977.

20. J ohnson, R. W., M. J . Propes, and Y. Shavit. Corticosterone modulates behavioral and metabolic effects of lipopolysaccharide. Am. J . Physiol. 270 (Regulatory Integrative Comp. Physiol. 39): R192-R198, 1996.

21. Kelly, F. J ., and L. S. J efferson. Control of peptide-chain initiation in rat skeletal muscle. Development of metyhods for preparation of native ribosomal subunits and analysis of the effect of insulin on formation of 405 initiation complexes. J . Biol. Chem. 260: 6677-6683, 1985.

22. Kimball, S. R., K. E. Flaim, D. E. Peavy, and L. S. J efferson. Protein metabolism. In: Diabetes Mellitus Theory and Practice (4th ed.), edited by H. Rifkin and D. J . Porte. New York: Elsevier 1990, p. 41-50.

23. Kimball, S. R., and L. S. J efferson. Regulation of initiation of protein synthesis by insulin in skeletal muscle. Acta Diabetol . 28 134- 139, 1991

24. Kimball, S. R., L. S. J efferson, P. Fadden, T. A. J . Haystead, and J . C. Lawrence. Insulin and diabetes cause reciprocal changes in the association of el F-4E and PHAS-I in rat skeletal muscle. Am. J . Physiol. 270 (Cell Physiol. 39): C705- C709, 1996.

25. Kimball, S. R., C. V. J urasinski, J . C. Lawrence, and L. S J efferson. Insulin stimulates protein synthesis in skeletal muscle by enhancing the association of elF-4E and elF-4G. Am. J . Physiol. 272 (Cell Physiol. 41): C754-C759, 1997.

26. Lang, C. H., J . Fan, R. N. Cooney, and T. C. Vary. IL-1 receptor antagonist attenuates sepsis-induced alterations in the IGF system and protein synthesis. Am. J . Physiol . 270 (Endocrinol. Metab. 33): E430-E437, 1996.

27. Li, J . B., J . E. Higgins, and L. S. J efferson. Changes in protein turnover in skeletal muscle in response to fasting. Am. J. Physiol. 236 (Endocrinol. Metab. Gastrointest. Physiol. 5): E222E228, 1979.

28. Manchester, K. L., and E. J . Harris. Effect of denervation on the synthesis of ribonucleic acid and deoxyribonucleic acid in rat diaphragm muscle. Biochem. J . 108: 177-183, 1968.

29. McNurlan, M. A., P. Essen, A. Thorell, A. G. Calder, S. E. Anderson, O. Ljungqvist, A. Sandgren, I. Grant, I. Tjader, P. E. Ballmer, J . Wernerman, and P. J . Garlick. Response of protein synthesis in human skeletal muscle to insulin: an investigation with L-[5-² $\mathrm{H}]$ phenylalanine. Am. J . Physiol. 267 (Endocrinol. Metab. 30): E 102-E 108, 1994.

30. Millward, D. J ., B. Odedra, and P. C. Bates. The role of insulin, corticosterone and other factors in the acute recovery of muscle protein synthesis on refeeding food-deprived rats. Biochem. J . 216: 583-587, 1983.

31. Minich, W. B., M. L. Balasta, D. J . Goss, and R. E. Rhoads. Chromatographic resolution of in vivo phosphorylated and nonphosphorylated eukaryotic translation initiation factor el F 4E: increased cap affinity of the phosphorylated form. Proc. Natl. Acad. Sci. USA 91: 7668-7672, 1994.

32. Nair, K. S., and W. F. Schwenk. Protein metabolism in diabetes mellitus. In: Diabetes Annual, edited by S. M. Marshall, P. D. Home, and R. A. Rizza. Elsevier Science Publ B V, Sara Burgerhartstraat, 1995, p. 159- 174.

33. Odedra, B. R., S. S. Dalal, and D. J . Millward. Muscle protein synthesis in the streptozotocin-diabetic rat. A possible role for corticosterone in the insensitivity to insulin infusion in vivo. Biochem. J . 202: 363-368, 1982.

34. Pain, V. M. Initiation of protein synthesis in eukaryotic cells. Eur. J . Biochem. 236: 747-771, 1996.

35. Pradier, P., and M. Dalle. Effects of corticotrophin-releasing factor and vasopressin on plasma adrenocorticotrophin molecular forms, aldosterone and corticosterone in young and adult rats and rabbits. Reprod. Fertil. Dev. 8: 111-116, 1996.

36. Preedy, V. R., and P.J . Garlick. Theresponse of muscle protein synthesis to nutrient intake in postabsorptive rats: the role of insulin and amino acids. Biosci. Rep. 6: 177-183, 1986. 
37. Rannels, D. E., A. E. Pegg, S. R. Rannels, and L. S. J efferson. Effect of starvation on initiation of protein synthesis in skeletal muscle and heart. Am. J. Physiol. 235 (Endocrinol. Metab. Gastrointest. Physiol. 4): E126-E133, 1978.

38. Rooyackers, O. E., and K. S. Nair. Hormonal regulation of human muscle protein metabolism. Annu. Rev. Nutr. 17, 457485, 1997.

39. Sapolsky, R. M., L. C. Krey, and B. S. McE wen. The neuroendocrinol ogy of stress and aging: the glucocorticoid cascade hypothesis. Endocr. Rev. 7: 284- 301, 1986.

40. Southorn, B. G., R. Palmer, and P.J . Garlick. Acute effects of corticosterone on tissue protein synthesis and insulin-sensitivity in rats in vivo. Biochem. J . 272: 187-191, 1990.

41. Svanberg, E., L. S. J efferson, K. Lundholm, and S. R. Kimball. Postprandial stimulation of muscle protein synthesis is independent of changes in insulin. Am. J. Physiol. 272 (Endocrinol. Metab. 35): E841-E 847, 1997.

42. Svanberg, E., H. Zachrisson, C. Ohlsson, B. M. Iresjo, and K. G. Lundholm. Role of insulin and IGF-I in activation of muscle protein synthesis after oral feeding. Am. J . Physiol. 270 (Endocrinol. Metab. 33): E614-E620, 1996.

43. Tessari, P., R. Barazzoni, M. Zanetti, E. Kiwanuka, and A. Tiengo. The role of substrates in the regulation of protein metabolism. Baillière's Clin. Endocrinol. Metab. 10: 511-532. 1996.

44. Tischler, M. E., M. Desautels, and A. L. Goldberg. Does leucine, leucyl-tRNA, or some metabolite of leucine regulate protein synthesis and degradation in skeletal and cardiac muscle? J . Biol. Chem. 257: 1613-1621, 1982.

45. Umpleby, A. M., and D. L. Russell-J ones. The hormonal control of protein metabolism. Baillière's Clin. Endocrinol. Metab. 10: 551-570, 1996.

46. Waalkes, T. P., and S. Udenfriend. A fluorometric method for the estimation of tyrosine in plasma and tissues. J . Lab. Clin. Med. 50: 733-736, 1957.

47. Williams, I. H., B. H. L. Chua, R. H. Sahms, D. Siehl, and H. E. Morgan. Effects of diabetes on protein turnover in cardiac muscle. Am. J . Physiol. 239 (Endocrinol. Metab. 2): E178-E 185, 1980.

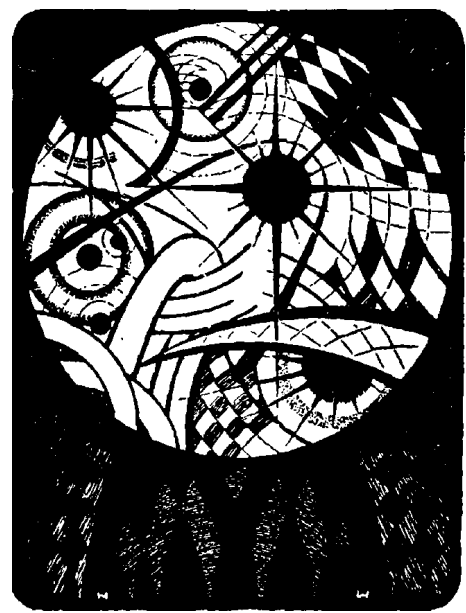

